\title{
Inventing Saikaku: Collectors, Provenance, and the Social Creation of an Author Molly C. Des Jardin
}

The first modern collection ${ }^{1}$ boasting to comprise a literary author's "complete works" in Japan, the 1894 Kōtei Saikaku zenshū (The Edited Complete Works of Saikaku; hereafter, Saikaku zenshū, or The Complete Works of Saikaku), is that of seventeenth-century author Ihara Saikaku. He is now considered a canonical figure in Japanese literary history but was relatively unknown to general readership before the 1890s. ${ }^{2}$ These two volumes in the Imperial Library (Teikoku bunko) series of popular literature were the first time that Saikaku's works were collected as a cohesive oeuvre, together under a single, consistent authorial name, and, I argue, the first time that this genre of collection manifested itself in the publishing world of the late nineteenth century. The texts we now consider to be Saikaku's oeuvre were made widely available in this deliberately constructed archive and, through this, were inextricably linked with its editors and other named contributors at the time. Saikaku zensh $\bar{u}$ was created in a moment in which this author was first becoming part of the conversation of modern literature in the late nineteenth century and, in a socially transparent way, reflects the wholesale invention of him that was in process at the time. Within this collection and at its moment of compilation in the late nineteenth century, Saikaku was transformed, via what I will call social provenance, into an institution unto himself through the presentation of private collections as a self-evident body of

\footnotetext{
${ }^{1}$ I use the word "modern" advisedly; I am referring specifically to the Japanese word kindai 近代, which in turn is interpreted as meaning the period from approximately 1868 through the early part of the twentieth century and a time of development in Japan. It is a way of motioning to this specific moment while also gesturing to the newly invented nature of this genre. I do not mean to associate this compilation with Westernization or a dichotomy with "premodern" Japan.

${ }^{2}$ 校訂西鶴全集. Ihara Saikaku. Kōtei Saikaku zenshū, ed. Ozaki Kōyō and Watanabe Otowa (Tokyo: Hakubunkan, 1894). Saikaku himself was popular and well known during his lifetime, but as far as literary historical figures, he did not rank among the pantheon of popularly canonical figures during the eighteenth and nineteenth centuries.
} 
work. This oeuvre simultaneously created, and was delimited by, the author's late-nineteenthcentury identity of one relevant to the question of what modern Japanese literature, and indeed modern Japan, would look like.

In the late nineteenth century, Saikaku fans, together, actively dug him out of used book shops and circulated his works first among each other, then to a specialized audience through coterie journals, and finally to the mainstream through mass industrial printing. In the process, they fundamentally invented Saikaku as an author, and not just any author — their author, one that belonged socially, intellectually, and literarily to them before anyone else. This is key to understanding not just the canonization of Saikaku but the process of canonization itself at this time in history and more broadly. Canonization does not simply happen, but is rather forced to happen by specific individuals acting together, whether cognizant of that collective action or whether it takes place implicitly. Saikaku zenshū speaks to us not just of Saikaku himself, but of the social infrastructure of fans that is the driving force behind the solidification of authorial identity, and of the pivotal role of the individuals that made up that social network in the very shaping of modern Japanese literature and the literary canon itself at a crucial point in literary history.

The Saikaku of the time before and leading up to Saikaku zenshū's publication and the Ihara Saikaku that exists today are substantially different figures. While Saikaku is still recognized as a poet of the haikai form - nicknamed the "twenty-thousand verse man" during his lifetime for an alleged marathon session of linked verse - he is now regarded almost exclusively as a masterful early writer of prose fiction in the style of what we now call the short story or novel. Donald Keene dedicates one of the only three chapters on fiction to Saikaku's short stories in his work on early modern arts and literature, World Within Walls, while a similar chapter for 
Saikaku's haikai poetry is not included; meanwhile, a more recent Columbia collection of early modern literature dedicates the sole author-focused early modern fiction chapter to Saikaku as well, and does not mention him within the poetry section at all. ${ }^{3}$ Yet Saikaku himself - writing under a variety of pen names and not uniformly under the name "Ihara Saikaku" - was barely discussed for a number of years save for a few scattered references. ${ }^{4}$ It is partly thanks to Saikaku zensh $\bar{u}$ that he has become the prose fiction author that has become so well known over the course of the twentieth century, with the part it played in making his work more widely and popularly accessible. We must remember, at the same time, that it is in fact the individuals who created and distributed Saikaku zensh $\bar{u}$ that did the real work of popularizing their favorite author: using new media technologies, they advocated for him during the time leading up to and surrounding the collection's publication, and were broadly known as those who introduced and popularized Saikaku. The story of this collection, and of making Saikaku a living author worthy of engagement, has much to tell us about the process of popularization, legitimization, and the very invention of a modern author.

What makes Saikaku zenshū remarkable, aside from being the first collection of its kind in the modern period, is its specification of which contemporary collector lent nearly every text for this typeset publication. I argue that looking at this "social provenance" in the collection's paratext reveals the very backbone of the popularization and canonization process, and is an essential feature of Saikaku's rise to prominence, not simply an indicator of other forces. Without the strong social network supporting Saikaku and his work at this time, with their ability to advocate for Saikaku and critical engagement with his work -- through their prominent place in

\footnotetext{
${ }^{3}$ Donald Keene, World Within Walls (New York: Holt, Rinehart and Winston, 1976) and Early Modern Japanese Literature, a Collection, 1600-1900, ed. Haruo Shirane (New York: Columbia University Press, 2002).

${ }^{4}$ The compilers of Saikaku zenshu attempt to gather some of those critiques in the second volume of their collection, including one by Kyokutei Bakin.

Copyright (C SHARP. This article first appeared in BOOK HISTORY, Volume 20, 2017, pages 274-306.
} 
the literary world, reputations, and social connections -- this writer may well have never become the canonical figure that he is today. It is imperative that we understand the ways in which social networks of advocates adopt and lionize a not-yet canonized, or even well known, figure, and introduce him as a model to emulate through both criticism and by example. It is this process of promotion, in addition to the reprinting and mass circulation of his works, that made him available both to readers of the day and to posterity, enabling his later canonization and our contemporary understanding of him as a pivotal figure in what became the standard narrative of Japanese literary history.

\section{Constructing a Social Archive}

Before turning to the social network and literary context that created it, I will introduce the collection itself as an object and as a publishing phenomenon, in the larger context in which it was situated both bibliographically and literarily. Saikaku zenshū was typeset and published on a large commercial scale by the major publisher Hakubunkan in 1894, and was edited by two members of the Ken'yūsha literary coterie, Ozaki Kōyō and Watanabe Otowa. ${ }^{5}$ It takes up two volumes of a larger series, the Imperial Library (Teikoku bunko), which focused on reprinting early modern literature (roughly from the mid-seventeenth century to the mid-nineteenth) for a late nineteenth-century audience; it should be emphasized that this series was composed of largely popular, rather than classical or academically canonical, literature, for consumption by a range of readers. ${ }^{6}$ Saikaku zensh $\bar{u}$ was created within this landscape of popular Edo-period (1603-1868) works, and within a wider context of Saikaku's popularization and the discursive

\footnotetext{
5 尾崎紅葉 (1868-1903) and 渡辺乙羽 (1869-1901). Otowa later married into the Ōhashi family, the owners of Hakubunkan, and changed his name to Ōhashi Otowa; he also edited and published the well-known Higuchi Ichiyō's Ichiyō zenshū in 1897. Ken'yūsha is discussed in more detail below.

${ }^{6}$ Indeed, it is hard to argue that there existed an "academic canon" at this point in Japan: while there were multiple educational canons of classics for different demographic groups and interests, a universal curriculum was not established at the time.
} 
space in which he was imagined. The volumes' form, content, and positioning are key to understanding collecting and compiling as a driving force behind the institutionalization and legitimization of a modern "Ihara Saikaku" within a still-contested Japanese literature, and indeed idea of literature itself, at this moment in time.

The Imperial Library series leading up to Saikaku consists of more popular works from early modern East Asia printed with a clear typeface and little prefatory material. The series starts off with widely known classics that were still being actively read, not to mention being adapted into kabuki plays, depicted in famous series of prints (such as artist Utagawa Kuniyoshi's series of warriors from The Water Margin), and even immortalized in popular tattoo motifs. These included Kyokutei Bakin's Eight Dogs, Tamenaga Shunsui and Ryūtei Tanehiko's works of light fiction, timeless tales of samurai loyalty such as A Treasury of Loyal Retainers, and Chinese classics like The Water Margin and The Romance of the Three Kingdoms that had been adapted in myriad forms over the years. They were living works of literature: they were texts that a lay person in the late nineteenth century might consider ones that should be familiar to anyone who would understand the world of popular culture. The Imperial Library's inclusions were hardly books that could be considered "discoveries" whose literary genealogies needed to be established and legitimized. Saikaku, too, is placed within this context: by inclusion in the series, he is positioned as a kind of new popular classic, an author who should become part of the Imperial Library reader's personal canon. Thus he was inserted into this "living literature" even as his works were introduced to general readers perhaps for the first time. This is key to understanding the process of his popularization; rather than being held up as an Edo-period author worthy of study, the discourse of his advocates was that of relevance to modern Japan and 
the worth of engaging him on the same terms with which they spoke about their contemporaries' writing.

Saikaku zensh $\bar{u}$ stands out from the other Imperial Library volumes in several ways. It contains a great deal of material about Saikaku in addition to his works themselves; this makes it an anomaly in the series, which typically didn't include much in the way of verbal paratext. It begins with two prefaces written by the editors themselves; they are clearly interested and invested in orienting and introducing Saikaku as an author with a distinct identity, worthy of serious study. Given that they and their colleagues adopted this author's style as a legitimate form of modern literature in their own writing, they had a great deal invested in making him similarly acceptable to others. One Saikaku zenshū preface is a short biography focusing on the history of his literary life and the milieu of his time, while the other is a lengthy critique citing historical criticism and arguing for his importance as a realist, even an anthropologist, and faithful cataloger of Genroku-period (1688-1704) customs. The collection ends with a large appendix that reprints a few works related to Saikaku in full, rather than only ones written by him. This is different from collections that simply compile works by an author: rather, it is a way to own Saikaku in full, and it is also a method for demonstrating that others had engaged with him as a legitimate author over time (whether they were critical of or praised him). It is not quite just for reading and enjoyment, as other Imperial Library installments may have been.

The collection's paratext does not stop with literary criticism about the content of Saikaku's writings, however. It is full of information about the source texts used, both the edition and the contemporary owner, recorded prominently next to the title of almost every work contained in the collection. No other contemporary collections went to the trouble of identifying owners of the texts that make up their content in such a comprehensive way, or indeed at all. For 
example, the story "Kōshoku ichidai onna" ("An Amorous Woman") is identified as having been in the collection of prominent Saikaku collector Awashima Kangetsu, a personal friend of editor Ozaki Kōyō and, as we will see, a deeply invested fan of Saikaku himself. In this way, the two volumes of Saikaku zenshū do more than simply identify collectors for posterity's sake: for anyone familiar with the social network of the literary establishment at the time, they also draw a map of those who were the advocates of Saikaku, those who literally owned him through their possession of texts as well as their prominent discourse about him in print.

Saikaku zensh $\bar{u}$ is a rich case for analysis of the ways in which a collection can be read as an object that is socially as well as intellectually constructed, and at the same time, it highlights the pieces that are missing in other collections of this kind. Given that collections of "complete works," especially those that are author-centric (kojin zensh $\bar{u})$, now virtually make up the world of Japanese literary study both in Japan and abroad, we must take note of the transparency of Saikaku's case: modern kojin zenshū often do not explain which versions of texts are printed inside their covers, and they generally obscure the contemporary sources of those texts. They transform the preservation of authors' works from a network of collectors and academic institutions with human actors to an opaque, directionless process of accumulation. Here, however, that network is laid bare and through this collection, we can see the human connections at work in collecting a newly-discovered author.

It is perhaps no coincidence that the modern science of archival theory and practice came into existence at roughly the same time as the compilation of Saikaku zensh $\bar{u}$, with the Dutch Manual for the Arrangement and Description of Archives published in 1898. This was the first time that archival principles and suggestions for practice were put into writing, and thus had a major influence of the field in the through its large number of translations (including into non- 
Western languages). ${ }^{7}$ This work focused, as archival theory would for a number of decades, on the importance of describing records and the best way of doing so. Here, the archival concept of provenance speaks most to us in making sense of Saikaku zensh $\bar{u}$ 's particular level of detail, not only regarding the origins of the "records" themselves - here, the bibliographic information of the first editions of published works - but also the record of the text's path to inclusion in Saikaku zensh $\bar{u}$. While the names of collectors indicated in a literal sense who possessed the texts themselves, their context outside of the collection communicates who socially possessed Saikaku: the literary groups with whom the collectors and collection editors were affiliated.

Provenance traditionally encompasses the path of ownership of an object chronologically, from its original creation to the present; social provenance is more synchronic and spatial. Its focus is on the living collectors through whose hands the texts passed in order to make up a part of Saikaku zenshu, and interestingly, it does not include the prior owners through time of those texts. Instead, we see an interest at the level of the physical object, and in specifying editions as unique rather than works as abstracted entities; we also find concern with which editions are located in whose currently existing libraries, and where they inhabit the space of late nineteenthcentury networks of collectors. There is less focus here on the history of the texts, and more on the structure of collecting and the discursive space of Saikaku in the contemporary moment. The social provenance included in Saikaku zenshū gives us a rare window onto the construction of the collection itself, and also onto the process of literary legitimization. But it would have done more than that for some of the collection's contemporaries: for readers with knowledge of the literary scene, it deliberately placed Saikaku within a literary movement and gave the collection a kind of currency that a less contextualized one might have. For contemporary readers familiar

\footnotetext{
${ }^{7}$ Terry Cook, "What is Past is Prologue: A History of Archival Ideas Since 1898, and the Future Paradigm Shift," Archivaria 43 (Spring 1997), 4.

Copyright (C SHARP. This article first appeared in BOOK HISTORY, Volume 20, 2017, pages 274-306.
} 
with the literary scene, this context would have been inseparable from their readings of the collection.

The zenshu (literally, "complete collection”) was a new form in the Meiji period, especially the kojin zenshū or individual author's complete collection. In China, collections with this appellation (pronounced quanji) existed prior to the late nineteenth century but were rare; more often, collections took the form of those referred to in Japanese as bunsh $\bar{u}$ ("collected writings") or bunsho ("book of writings"); in addition, there were memorial editions such as those whose titles ended in $i k \bar{o}$ (“in memory of"). ${ }^{8}$ Author Yoda Gakkai, writing as Yoda Hyakusen, for example, lists several bunshū collections in an 1889 Kokumin no tomo magazine feature listing various figures' "top ten" books; it is probable that these Chinese-style collections, already established both in China and Japan at the time, were more influential than any Western concept of an omnibus. ${ }^{9}$ Collections such as bunsh $\bar{u}$, and even those rarer books with zensh $\bar{u}$ in the title that were disseminated in China, were not necessarily the same as modern zensh $\bar{u}$, however. None truly implied that they contained the "complete" works of the scholars or literati in question. They were understood in China, as well as Japan, as containing selections or works otherwise unobtainable easily, not the complete published or anthologized writings of that person. ${ }^{10}$

This is not so different from what I will refer to as $i k \overline{s h} \bar{u}^{11}$ ("memorial collections"), rather than the twentieth- and twenty-first-century zensh $\bar{u}$ that we recognize now. The reason for this distinction is that earlier collections were often compiled in memory of a teacher or scholar

\footnotetext{
${ }^{8}$ The three Japanese terms are 文集, 文書, and 遺稿, respectively. A few zensh $\bar{u}$ can be found in the seventeenthcentury compendium Siku quanshu, which contains these compilations of individual authors' "complete" writings with titles in the format (name) quanji.

9 "Shomoku jisshu," Kokumin no tomo 48 supplement (April 1889): 5. Gakkai is far from alone in listing collections whose titles include this phrase.

${ }^{10} \mathrm{I}$ am indebted to Timothy Clifford for his perspective on Chinese understandings of collections and their contents; private correspondence.

11 遺稿集

Copyright (C) SHARP. This article first appeared in BOOK HISTORY, Volume 20, 2017, pages 274-306.
} 
by his family or disciples; he was often a literatus who specialized in the study of Chinese works such as poetry or philosophy. The collections generally contained a preface (typically in literary Chinese) about the individual in question, a title including the word sensei ${ }^{12}$, and unpublished manuscripts by that scholar. They did not contain literary criticism about the scholar, nor were they disinterested academic collections; rather, they brought together documents collected from the family and disciples of the deceased. This is considerably different from later zensh $\bar{u}$ collections that contain a great deal of scholarship (often in the form of aaidai $^{13}$ or "explications") and annotations, as well as scholarly prefaces; in addition, collections now contain as many works as possible, not just those that were unpublished (although they often contain such works and correspondence as well).

In fact, many of the early zensh $\bar{u}$ appearing at the turn of the twentieth century are not as similar to later zenshū as Saikaku zenshū itself was. They are more part of the lineage of $i k \bar{s} h \bar{u}$, even if they are flipped: they were put together and edited by the friends and mentors of the deceased, not disciples or family, and they contained reprints of already-published work, were often put out by the same publisher that distributed those works to begin with, and published almost immediately after the deaths of their respective authors. ${ }^{14}$ They contain heart-rending prefaces in memory of these authors, several of who died of suicide or disease at quite young ages (Higuchi Ichiyō at 24, Kitamura Tōkoku at 26, both in the mid-1890s), and if they contain

\footnotetext{
12 先生; perhaps a carryover from China, pronounced xiansheng in Mandarin, where this word was akin to "sir" rather than "teacher" or "mentor" as in Japan.

13 解題

${ }^{14}$ There are several interesting turn-of-the-century cases that highlight the speed with which these $z e n s h \bar{u}$ were published and the problems they introduced for reprinting already-published works. The 1897 Ichiyo zensh $\bar{u}$ was first published only a month after Ichiyō's death, but her works were largely published by the same Hakubunkan (and which published Saikaku zenshū three years before that). At the same time, Kawakami Bizan's 1909 Bizan zensh $\bar{u}$ was put out in two outwardly identical editions published by both Hakubunkan and Shun'yōdō, who couldn't come to an agreement on exchanging copyright for works that each had distributed when he was alive. This situation is actually explained in the zensh $\bar{u}$ prefaces quite openly.
}

Copyright (C SHARP. This article first appeared in BOOK HISTORY, Volume 20, 2017, pages 274-306. 
something we might call kaidai those pieces are generally memories and personal experiences of the authors, not explications of the content of their works. ${ }^{15}$

While direct evidence that Ozaki Kōyō and Watanabe Otowa read Western collections of complete works is scant, however, and we can't necessarily say that they based Saikaku zenshū on such examples, the widespread presence of foreign literature circulating among Meiji intellectuals and literati meant that the editors could hardly have been ignorant of their existence. In fact, the 1889 article in Kokumin no tomo referenced above -- the same publication and year in which the critical essay "Ihara Saikaku," discussed below, appears -- featured lists of "ten books" that intellectuals and well known figures "said were important to them and that they would recommend to young people to read." ${ }^{16}$ As Brian Dowdle notes, "these lists suggest that, in the mid-Meiji literary field, European, Chinese, and Japanese texts each had their place and adherents," demonstrating the wide-ranging taste and reading habits of the type of individual who would publish in or even read such a publication, and this very one often contained the works of Ken'yūsha members and their peers. Aikawa Masamichi lists Chimakatsu Monzaemon chosaku zensho, or The Complete Works of Chikamatsu Monzaemon, a Genroku playwright, as a recommendation, indicating that the idea of an author's complete works was not foreign to writers of the time. ${ }^{17}$ These can't necessarily be taken as book titles verbatim, however: authors also list "the works of Chikamatsu Monzaemon," for example, not by title but as "works" in a descriptive sense, and additionally many list various bunshū or poetry collections -- for example, "the collected poetry" or shish $\bar{u}^{18}$ It is nearly impossible in this article to tell if the writers are referring to a specific title or a general description. We also find that "[Charles] Dicken's (sic)

\footnotetext{
${ }^{15}$ Kitamura Tōkoku's 1902 Tōkoku zenshū contains over twenty pages of such memories by his friends and colleagues from the Bungakukai coterie.

${ }^{16}$ Brian C. Dowdle, "Why Saikaku Was Memorable but Bakin Was Unforgettable," Journal of Japanese Studies 42 , no. 1 (January 2016): 108.

17 Ibid., 14.

${ }^{18}$ The word used multiple times here is chosaku 著作, which easily translates as "works." Shishū is 詩集.

Copyright (C SHARP. This article first appeared in BOOK HISTORY, Volume 20, 2017, pages 274-306.
} 
Works" is listed as a favorite of multiple writers, Hatoyama Kazuo specifies the "Works of Herbert Spencer" and "Works of Lord Lytton" as recommendations, and another writer ("a certain doctor"19) lists numerous "Works" such as those by Thackeray, George Eliot, and Goldsmith. ${ }^{20}$ Extrapolating from this, we can see that at least the word and concept of "works" was familiar, and it is conceivable that a Western volume of an author's "Works" could have partly served as a model for the collection.

Yet Saikaku zenshū still stands out, despite its precursors, in contrast the Western omnibus as well as the bunshu and $i k \bar{o} s h \bar{u}$. It is a collection of both the "complete" literary works by and literary criticism about a long-dead author, one who is not personally remembered by the editors outside of their contemporary experiences of his work. His work is advocated not in the context of bereavement but rather literary appreciation and engagement with the content, not the individual. We can see Saikaku zenshū not just as one of the first modern collections of previously-published work boasting to actually be "complete" in its paratext, but as the beginning of the lineage of what later came to be ubiquitous in literary study and a genre called $z e n s h \bar{u} .^{21}$ Not only did it play a part in the canonization process by making Saikaku's works available "whole" and more widely, but it also reflects the efforts at popularization by a specific social group who took literary and personal ownership of the author. I will now turn to that social group, the literary coterie Ken'yūsha and their peers, who were the actors involved in the compilation, editing, and dissemination of Saikaku zensh $\bar{u}$, and who created the context for its potential reception.

\footnotetext{
${ }^{19}$ Nanigashi Hakase 某博士

20 "Shomoku jisshu" (Kokumin no tomo 48) 1, 15.

${ }^{21}$ I distinguish this collection as claiming to be complete not simply because of the rhetoric of the title, but specifically because of its inclusion of a bibliography of Saikaku's works that one could compare against what is included in the two volumes. It claims, through this, to be the exhaustive and authoritative reference to Saikaku, the "complete Saikaku," not just a complete collection of his works.

Copyright (C SHARP. This article first appeared in BOOK HISTORY, Volume 20, 2017, pages 274-306.
} 


\section{Ken'yūsha and the Space of Literature}

It is key to understand that editors of the Saikaku zensh $\bar{u}$, and their friends who lent copies of the texts that made it up, by and large belonged to a single social and literary group, Ken'yūsha, or "Friends of the Inkstone." Ken'yūsha began in the mid-1880s as a group of friends who met in school and continued to the early part of the twentieth century. This group was one of the most influential coteries of the mid-Meiji period, led by a man who would become the best selling author of the Meiji period, Ozaki Kōyō. Its first wave of members also included such well-known writers as Kawakami Bizan, Ishibashi Shian, and Iwaya Sazanami. Kōyō himself was one of the two editors of Saikaku zenshu, and the other, Watanabe (later Ōhashi) Otowa was also a Ken'yūsha affiliate. The activities and relationships we find in Ken'yūsha, and between the group and its rivals, reveal much about the social space of collecting and publishing in the midMeiji period. Moreover, it gives us an avenue for understanding the ways in which writers were coming of age at a time of great change, and negotiating a fluid landscape of ideas about literary history and genealogies.

Ken'yūsha, like other literary groups of the time, stands out as one that worked together collaboratively, writing under multiple pseudonyms and publishing their serial works alongside each other in the same textual social space, namely their journals such as Garakuta bunko and its successors Bunko, Edo murasaki, and Shöbungaku, to name several. Garakuta bunko was, at the beginning, hand-written and circulated physically among the members, all living in proximity to each other in Tokyo and inhabiting the same social and intellectual spaces. Members passed around the first eight issues of the "magazine" from hand to hand, making margin notes and commentaries before giving the issue to the next person. Only one copy was made and it was shared collectively among the members of the group. The group's social and physical aspects 
were crucial to its formation and sustainability as a literary network in the mid-to-late 1880s, when it began and flourished.

Notably, the first printed issue of Garakuta bunko (still quite limited in circulation) lists not just all of the ostensible members of Ken'yūsha but also their locations in the physical world, as well as the founding members who introduced them to the coterie. In all, the members tend to be located in Tokyo but one can be found as far afield as southern Japan and even other countries. But just as key is the social map that guides us through the web of Ken'yūsha's membership, which tells us a great deal the process of how group was constituted in the first place. This list demonstrates the way in which Ken'yūsha thought of itself collectively in a double geography: one that was grounded in the physical world but also in a networked space that consisted of links between core group members and those who had to be connected to it through personal acquaintance. It additionally emphasizes a kind of exclusivity in the group, one which requires members to be introduced — not simply to find and join the group on their own — and to make that allegiance to a founding member clear.

It is important to remember that Ken'yūsha was an entity concretely grounded in the social scene of Tokyo, with members regularly encountering each other and sharing pastimes as well as networks of colleagues and friends. Their advocacy of a certain kind of literature emerged partially from that friendship and shared intellectual space: without affiliate Awashima Kangetsu's personal interest in unearthing the history of Japan for the purpose of better explaining it to foreigners, and own his fascination with Edo-period writers, Saikaku may never have been introduced to Kōyō and his colleagues, and might not have been advocated for and reprinted as widely as he ultimately was. 
Those very same friends lent each other Saikaku's works to hand-copy if they could not afford their own editions; he literally circulated by hand among an innovative new generation of writers seeking to create their own version of modern Japanese literature. ${ }^{22} \mathrm{Koy} \overline{\bar{o}}$, in particular, made the effort to copy such long works by hand, desiring to emulate the styles in his own work. ${ }^{23}$ This heritage of Edo writing guided the work of Kōyō and his friends as they searched for a new modern Japanese literature, which many writers were doing at the time in styles that ranged from traditional literary language to the unification of spoken and written Japanese with genbun'itchi style. Various modes of writing were taken up multiply by the same authors, such as Kōyō and his colleagues, who did not restrict themselves to a single method of storytelling. In fact, we could see this time most accurately as one of broad experimentation and linguistic play. The works produced often mixed literary styles, and Kōyō himself did so in gazoku setchū style, which mixed colloquial dialogue with literary narrative. All were attempting to create a modern written language and literary style appropriate to the new literature of the time and for the future.

Ken'yūsha's styles often differed markedly from those writers that standard literary histories now identify as "modern," such as Tsubouchi Shōyō and Futabatei Shimei, who experimented with genbun'itchi style in the 1887-1889 novel Ukigumo (Floating Clouds). These writers were attempting to create a written vernacular, and it is Shimei's style which eventually won out in creating a new style of written Japanese that is used more or less in the same form today. But at the time their style was new and controversial, and their writing philosophy a reaction to the question of what modern literature should, or even could, look like in Japan. Shōyō wrote what is now one of the most famous works of Meiji literary criticism, Shōsetsu shinzui (The Essence of the Novel) in 1885, promoting the introduction of ninjō, or human

\footnotetext{
${ }^{22}$ Katsumoto Sei'ichirō, "Rohan to Kōyō," in Rohan zenshū furoku (Tokyo: Iwanami shoten, 1980), 23-24.

${ }^{23}$ At the same time, Kōyō borrowed liberally from English and other European literature; his style was a mix of influences both Japanese and foreign, much like other writers of the period.

Copyright (C SHARP. This article first appeared in BOOK HISTORY, Volume 20, 2017, pages 274-306.
} 
emotion, into stories, as well as the depiction of people's everyday lives and customs, or fiuzoku setai. As Atsuko Ueda has argued, Shōsetsu shinzui did not invent these terms, nor their promotion, for literature, but rather it was engaging in a field already full of what she calls "Shōsetsu shinzui clichés," a discursive field in which Shōyō and Shimei, as well as Kōyō and other writers, were experimenting with their various styles. ${ }^{24}$ It was a field in which the focus of literature was under active discussion, and we must also keep at the forefront the fact that "literature" itself as a term and a "field" did not exist as we now know it; nor was the word shōsetsu, often translated as "novel," an actual literary form or genre that was generally agreed upon. This field was a space for experimentation of all kinds, and mid-Meiji writers seized the opportunity. As time went on, Kōyō led the way in developing another style: one based on the work of seventeenth-century Saikaku. It was partly through this advocacy that Ken'yūsha began to create an identity for itself in the literary scene of the mid-Meiji period and entered debates over what modern Japanese literature should look like.

\section{The Discovery of Saikaku}

Given that the author we now know as Ihara Saikaku was quite obscure at the time leading up to Saikaku zenshū's publication, that it would be compiled at all and, moreover, included in a series of much more popular works of fiction, seems unlikely now. The explanation lies in the collecting of Saikaku's works by a few, passionate readers from used bookstores in the mid-tolate 1880 s, and the reprinting of these works by the very same people in their coteries' journals. This period is often called the "Genroku revival" (Genroku being the era in which Saikaku wrote) or a "rediscovery" of Saikaku. I argue, however, that the initial collecting period was not

\footnotetext{
${ }^{24}$ Atsuko Ueda, Concealment of Politics, Politics of Concealment: The Production of "Literature" in Meiji Japan (Stanford: Stanford University Press, 2007), 15.

Copyright (C) SHARP. This article first appeared in BOOK HISTORY, Volume 20, 2017, pages 274-306.
} 
a re-discovery, but the invention of Saikaku as an author of prose fiction, one who did not previously exist with such an authorial identity or even the single, stable authorial name of Ihara Saikaku. The dissemination and adaptation of a select set of his works helped to establish an authorial identity that did not exist prior to this moment. His promotion culminated at the time that Saikaku zensh $\bar{u}$ was published in 1894, and was accompanied and followed by discourse in many outlets on his literary merit, his place in literature past and present, and his influence on contemporary writers. This third stage of Saikaku invention, then, can be called a time of the establishment of literary legitimacy, when, through mass reproduction of his works, particularly in this collection, he became a modern institution unto himself.

Saikaku's discovery was characterized by literary critic Yone Noguchi, writing only a few years later in 1904 for an American audience, as his having been "picked out ... from a wastebasket of a certain second-hand shop in Kanda" by those disillusioned with the West and determined to resurrect what they considered traditional Japanese literature - but both in spirit and in historical fact, it is far from reality. ${ }^{25}$ The invention of Saikaku in the 1880 s took place not by chance, but by the deliberate efforts of well-read collectors who, fascinated by the references they encountered in the essays and memoirs of their favorite Edo authors, ${ }^{26}$ spent untold hours haunting any number of bookstores in Tokyo looking for rare or valuable editions of his works, even going as far as Osaka in hopes of coming across a good find to "store carefully away in a book box." 27

\footnotetext{
${ }^{25}$ Yone Noguchi, “The Evolution of Modern Japanese Literature,” The Critic 3, no. 44 (March 1904): 262.

${ }^{26}$ Awashima Kangetsu recounts that it was through Santō Kyōden that he read about Saikaku; Kyōden in turn spoke about author Ryūtei Tanehiko. Awashima Kangetsu, "Meiji jūnen zengo," in Bon'un 'an zatsuwa (Tokyo: Heibonsha, 1999), 32-33.

${ }^{27}$ Sanmai Dōjin [Miyazaki Sanmai], "Watashi to Saikaku," Kōchō 5 (1906): 12.

Copyright (C SHARP. This article first appeared in BOOK HISTORY, Volume 20, 2017, pages 274-306.
} 
In a talk given decades later to an antiquarian book society, entitled "Watashi to Saikaku" ("Saikaku and I"), novelist and collector Miyazaki Sanmai ${ }^{28}$ dwells on the tactile, emotional, and social experience of collecting in the 1880s. Sanmai vividly recalls searching for Saikaku's works: he depicts the districts and bookstores that he haunted; the appearance and prices of all of the editions that he found; the personalities of the shop owners; and taking meandering walks with his literary acquaintances. His characterization of this period stands out as one of constant and crucial social interaction between collectors.

From that point [when I became acquainted with Saikaku's work], I became quite close with those three, Ozaki Kōyō, Kōda Rohan, ${ }^{29}$ and Awashima Kangetsu. ${ }^{30}$ At Kangetsu's invitation, 'the rare book club,' as we called it, got started up. You see, unlike our clubs and mutual interest groups of today, there was just absolutely nothing out there for us. ${ }^{31}$

It was these four, as well as fellow bibliophile Uchida Roan ${ }^{32}$ and editor Watanabe Otowa, who made up the cast of characters in the invention of Saikaku. Kangetsu, Rohan, and Roan all leave us with details of their time collecting and enjoying Saikaku, and all were known widely at the time as the ones who both introduced and evangelized Saikaku to the literary world. ${ }^{33}$ At this time, Sanmai recalls, "even the word 'rare book' did not yet exist." 34 Thus, there were few established methods for getting ahold of such texts, such as the rare book club to which Sanmai spoke. The possibility of pooling resources, including tips on which works were actually authored by Saikaku, suggestions for other new books or authors, as well as simply finding likeminded colleagues, were based almost entirely on social networks that formed in bookstores and through collectors as intermediaries.

28 宮崎三昧 (1859-1919).

29 幸田露伴 (1867-1947).

30 淡島寒月(1859-1926).

${ }^{31}$ Ibid.

32 内田魯庵 (1868-1929). Roan later helped to run the bookseller and publisher Maruzen in addition to writing.

${ }^{33}$ While all wrote and published fiction and essays, Kōyo and Rohan stand out from the others in becoming known as two of the most talented writers of the day and are now considered major novelists of the late nineteenth century. Kōyō, in particular, was the most popular and best selling author of the mid-to-late Meiji period.

${ }^{34}$ Ibid.

Copyright (C) SHARP. This article first appeared in BOOK HISTORY, Volume 20, 2017, pages 274-306. 
These intermediaries were the ones who provided access in the first place, too. Kangetsu recounts showing the Saikaku texts he had begun to collect to both Kōyō and Rohan, and even gives the date: sometime after he moved to Yushima, Tokyo, in April 1880, and $1886 .{ }^{35}$

Saikaku's works circulated, at the least, to Kōyō and Rohan through Kangetsu's collection, and from these borrowed texts they painstakingly hand-copied their own to keep. ${ }^{36}$ This is an important aspect of Saikaku's discovery and promotion in the nineteenth century, for the very writers who adapted his style to their own work, Ozaki Kōyō and Kōda Rohan, were still teenage students at the time and able to read his works only by borrowing them from Kangetsu. Thus, the very discovery of Saikaku - the first step toward his 1894 collection - was mediated by an older mentor, one whose goodwill and encouragement helped to cultivate their existing interest in early modern fiction.

Not only did these young men regularly encounter each other in their bookstore circuit and traverse the same physical space day after day, they also depended almost completely on their relationships with the booksellers themselves in order to conduct their collecting in the first place. As Sanmai remembers, his time in Osaka - Saikaku's hometown - was spent looking passionately for books that he expected to be "relatively more abundant," but "no matter how many days I spent and how vigorously I searched for them, there were absolutely none to be found. ${ }^{, 37}$ In three years, he managed to find only one book. Yet, upon returning to Tokyo, several years later he "went on a whim to Saitō's [bookstore] in Ikenohata, and upon asking [the proprietor] if he had any old books, Mr. Saitō grinned proudly and responded that he had some things to show" him. It was at this visit that Sanmai discovered a trove of Saikaku's works, including the famous "Kōshoku ichidai otoko" ("An Amorous Man"), and "cried out, "What an

\footnotetext{
${ }^{35}$ Awashima, "Meiji jūnen zengo," 32.

${ }^{36}$ Katsumoto, 23-24.

37 Sanmai, 13.

Copyright (C SHARP. This article first appeared in BOOK HISTORY, Volume 20, 2017, pages 274-306.
} 
old copy!'” before happily snapping it up. ${ }^{38}$ At yet another bookstore, although Sanmai found nothing to buy "no matter how many times [he] went," because the atmosphere of the "mom and pop" store was so agreeable, he found himself staying there "chatting for about half a day" at a time, and finally his persistence paid off: “smiling, they told me they'd been waiting for me and pulled out a copy of 'Budō denraiki' ('A Record of the Legacy of Martial Arts').”39

Without such persistence and an established social relationship, Sanmai might have spent his years just as he had in Osaka, without making such a pleasing discovery. Although his collection does not make up a part of Saikaku zensh $\bar{u}$, he gives a vivid account of the experience of collectors at this time, and makes it possible to picture those who did contribute their printings to the project operating within the same socially based system. The social networks crucial to creating a Saikaku archive and forming the basis for his promotion as a specific kind of author, then, were not just those of the literary establishment and prominent authors whose names have been passed down through time. Without relationships built up over time with booksellers - as well as their own, largely uncredited research, discovery, and goodwill - we might not have the body of work collected in Saikaku's first collection and thus passed down as his oeuvre to the present.

\section{Saikaku the Phenomenon}

In Sensational Designs, Jane Tompkins offers a typical definition of a classic work: "[one] that has withstood the test of time.. ${ }^{\circ 0}$ Clearly, Saikaku - now considered a classic author of early modern fiction but neglected for nearly two centuries - does not stand up to this definition.

However, it is difficult to understand his appearance in the late nineteenth century simply from

\footnotetext{
38 Ibid., 13.

39 Ibid., 14.

40 Jane Tompkins, Sensational Designs: The Cultural Work of American Fiction 1790-1860 (New York: Oxford University Press, 1985), 3.

Copyright (C SHARP. This article first appeared in BOOK HISTORY, Volume 20, 2017, pages 274-306.
} 
looking at standard literary histories that praise him as an innovative and talented seventeenthcentury writer, and one of prose fiction. As Tompkins argues, "a literary classic is a product of all those circumstances of which it has traditionally been supposed to be independent" and is a part of a canon that "not only can but will change along with the circumstances within which critics argue." In other words, the canon is what is available to, and chosen by, critics for discussion at a given moment and is what critics choose to engage with; in order for them to do so, of course, the work must generally be readily accessible, such as in a collection like Saikaku $z e n s h \bar{u}$, rather than in the centuries-old editions that collectors dug up in bookshops. In order to understand Saikaku's elevation to an author worthy of a place in a discussion of modern literature, then, we must look to the historical conversation in which debates were taking place about how fiction should be written, which literary forms should be adopted, and what ought to be considered modern Japanese literature. This is the context that will allow us to understand the potential for reception of Saikaku zensh $\bar{u}$, and its contribution, through its construction as well as very existence, to the popularization and, later, canonization process.

Just as the members of Ken'yūsha learned of Saikaku through the circulation of his works among their group, others learned of Saikaku from the reprinting of those works. ${ }^{41}$ Readers introduced to Saikaku in typeset versions experienced him in myriad literary and visual contexts, but these versions always carried the name "Ihara Saikaku," and not any of his other numerous pseudonyms. This is the point, then, when Saikaku was becoming the unified author that we know today, consolidated by his editors from multiple names into a singular, consistent identity that did not exist prior to the late 1880s. Yet despite that singular identity in terms of his name and the contents of his oeuvre (prose fiction), encounters with Saikaku in different types of

\footnotetext{
${ }^{41}$ It is important to note that just as Saikaku zenshū contained no haikai poetry, Saikaku's poetry was likewise not reprinted in these venues, thus establishing his identity further as a prose writer with the single name of "Ihara Saikaku."

Copyright (C) SHARP. This article first appeared in BOOK HISTORY, Volume 20, 2017, pages 274-306.
} 
publications could have quite different contexts. Reading Saikaku in the magazine Shigarami zōshi (published by the well-known Mori Ōgai's coterie Shinseisha ("The Company of New Voices")) would lead the reader to understand his work in the context of other classical literature contained in an appendix separate from the main body of the magazine, which was otherwise dedicated to current literature and criticism. ${ }^{42}$ Meanwhile, Saikaku's works were also published in the literary group Ken'yūsha's Bunko, ${ }^{43}$ as well as in the boys' magazine Shōnen 'en. ${ }^{44}$ It would yet again be a different experience to encounter his "Kōshoku go'nin onna" or "Saikaku omiyage" in book form published by Sansan Bunbō ${ }^{45}$ in 1891, or the same "Kōshoku go'nin onna" published as a book in 1890 by Maruzen.

In the case of coterie publications, Saikaku was often presented as what we may call "living literature;" it was integrated into sections that contained contemporary, currently serialized works, and surrounded by a huge number of literary styles being undertaken by writers of the day. Publishing Saikaku in the context of magazines full of contemporary serial writing would have encouraged readers to see him as current and relevant to the Meiji literary world, rather than an antiquarian fascination. At the same time, encountering him in typeset book form, whether a standalone work or a compilation like Saikaku zensh $\bar{u}$, would present him as even more legitimate, and again, contemporary - a writer encountered in the context of modern, Western-style printing and binding technologies, not Japanese-style, heavily-illustrated woodblock printing.

We must remember, however, that the reprinting of Saikaku was brought about by human actors, and often the very same ones who had collected him in the first place. Kangetsu is

${ }^{42}$ Ihara Saikaku, "Kōshoku nidai otoko,” Shigarami zōshi 1 (October 1889): 47-48.

${ }^{43}$ Ihara Saikaku, "Kōshoku ichidai onna," Bunko 24 (July 1889): 47-49.

${ }^{44}$ Ihara Saikaku, "Yakusoku wa yuki no asameshi," Shōnen'en 55 (February 1891): 16-17. Despite the reprint of Saikaku's work here in a youth magazine, it comes with a caveat that most of his other work is never to be read by boys!

45 三三文房

Copyright (C) SHARP. This article first appeared in BOOK HISTORY, Volume 20, 2017, pages 274-306. 
referenced in more than one publication as having brought Saikaku into the world and being "the authority on Saikaku," as Uchida Roan puts it in an article naming and evaluating the "three greatest Japanese novelists" - including, of course, Saikaku as the most prominent. ${ }^{46}$ His control of physical works as a collector and connoisseur, then, had a significant influence on the literary world, despite the fact that he himself was not pursuing literary writing as a primary path. Just as with Saikaku zensh $\bar{u}$, it is the collections of individuals like Kangetsu who allowed Saikaku to be reprinted in the first place, and ensured that he could even enter the conversation of what constituted literature at the time. Yet, although his experimental, Saikaku-style publications (and the original Saikaku works he lent to be reprinted) appeared in Ken'yūsha-affiliated publications, his influence was not limited to that literary group; another reference to Kangetsu, under the name Saiseki, yet another allusion to Saikaku's name, as having a crucial role in the introduction of that author is from an unrelated literary journal, Iratsume. ${ }^{47}$

Saikaku as an author is not only contextualized in terms of the specific individuals and groups that promoted him in the literary world; he is mediated by writers' personal and social experiences in their own attempts at literary criticism as well. Rohan and Kangetsu co-wrote a piece in 1889 in Ken'yūsha's Bunko entitled "Ihara Saikaku o tomurau bun” (“A Piece Mourning Ihara Saikaku") in which they jointly express their admiration while lamenting a death that took place two hundred years before. Rohan later published his more critical essay "Ihara Saikaku" alone in the leading periodical Kokumin no tomo, the longer work here ranging from historical treatment of Saikaku to current reception. Frustrated at "still having not seen any critical analysis of Saikaku's writing," Rohan sets out to do this here, yet meanders through everything from his

\footnotetext{
${ }^{46}$ Fuchian Shujin [Uchida Roan], "Nihon shōsetsu no sandaika," Shōbungaku 1 (October 1889): 11.

${ }^{47}$ Inuguchi, “Tsuretsure," Iratsume 81 (March 1891): 136. Iratsume was edited by Yamada Bimyō, but only after he had left Ken'yūsha.

Copyright (C) SHARP. This article first appeared in BOOK HISTORY, Volume 20, 2017, pages 274-306.
} 
own reading experience to debates on Saikaku's level of erudition (including opinions from both Kangetsu and Kōyō), to the fervent adoration that his colleagues show for the author. ${ }^{48}$

The emotional attachment of Saikaku's admirers to his works comes through even here. Along with abundant historical and contemporary detail, and clear indication of extensive research into the topic of Saikaku's reception over time, Rohan includes reactions such as Uchida Roan's admission that Saikaku's books made him "forget [himself] completely, both in body and mind." 49 Rohan's own lengthy impression as a reader includes the new experiences that he had not only on his second reading of the works, but even on a third reading. ${ }^{50}$ At the same time, Rohan's introduction to the piece shows him to be just as moved by Saikaku: he recounts a dream he himself had only a few weeks before in which he was strolling in a field with none other than Kangetsu, “discussing Saikaku as we went," even specifying its exact date. ${ }^{51}$

Yet the article comes to a close on a more serious topic: where is the place of Saikaku in contemporary literary debates? Rohan struggles with placing him in either the current realist $(\text { shashin-ha })^{52}$ or idealist $(r i s \bar{o}-h a)^{53}$ movements, although he concludes that "saying that he is a realist is probably closest to the mark."

Not only can we come to know the customs and feelings of people from two hundred years in the past as though we are looking at a mark on the palm of our hands, we can also see that even now the days and nights of events that Saikaku has painted for us are still occurring. ${ }^{54}$

At the same time, however, he finds value in Saikaku's insight into the human heart, and in this he sees "a great idealist." "There are a great number of places in which we see depicted the

\footnotetext{
${ }^{48}$ Koda Rohan, "Ihara Saikaku," Kokumin no tomo 83 (May 1890): 27.

49 Ibid., 31.

50 Ibid., 29.

51 Ibid., 27.

52 写真派

53 理想派

${ }^{54}$ Ibid., 31. We see here again those Shōsetsu shinzui-esque words such as "customs" and "feelings," demonstrating how widespread they were in the literary conversation of the time: perhaps something that, given the focus of Saikaku's work, made him even more relevant to the time.

Copyright (C SHARP. This article first appeared in BOOK HISTORY, Volume 20, 2017, pages 274-306.
} 
vicissitudes of the human heart, just as it is," Rohan writes. ${ }^{55}$ Rohan sees Saikaku as part of a living, contemporary conversation, one in which writers and critics argued over how best to express the rapidly-changing human condition in the world of Meiji Japan, and clearly considers this the most appropriate way to judge Saikaku's merits. These critiques are all part of inventing Saikaku the modern author, one who writes prose fiction that is worthy of being evaluated on the same terms as other "modern" literature, with words used to describe the aims and effects of literature at the time, especially contemporary literary efforts. Rohan brings Saikaku to the present completely, not just insisting that one can understand the past by reading his work, but that the events in Saikaku's stories "are still occurring." His stories are just as relevant to the reader as any other contemporary literature, and Saikaku can be considered a living author rather than an obscure relic.

Aside from his own conclusions, Rohan, in detailing Saikaku's contemporary reception, also paints a rich network of colleagues by name who have responded to Saikaku, including Roan as well as translator and author Morita Shiken. ${ }^{56}$ Rohan's naming of others involved in the present Saikaku phenomenon resembles Saikaku zenshū's list of source text owners: he links the invented author to a concrete literary social scene. These are but a small section of the list of writers that Kangetsu remembers distributing his Saikaku collection to, and "happily, because I had [my collection of] Saikaku's books ... I was able to show them to all of these others," fulfilling a desire to share what he considered great writing to those with a mutual interest. ${ }^{57}$ Yet these were not colleagues who simply shared social ties: as we have seen with Kangetsu, Otowa, Kōyō, Rohan, Roan, and Shiken (whose work appears right next to "Ihara Saikaku" in Kokumin no tomo), these are a group of colleagues who published side-by-side in the same public space

\footnotetext{
${ }^{55}$ Ibid. This is extremely reminiscent of Shōyō's advocacy of expressing human emotion in literature.

56 森田思軒. 1861-1897.

57 Awashima, “Meiji jūnen zengo," 32.

Copyright (C SHARP. This article first appeared in BOOK HISTORY, Volume 20, 2017, pages 274-306.
} 
and co-authored pieces that praised their favorite author. The archive Kōyō, Otowa, and their collector friends created in Saikaku zensh $\bar{u}$ is buried in this network of intellectually, socially, and physically close writers. It is one inextricable from its contemporary context and from its social provenance as inscribed in the collection itself.

\section{Inventing Saikaku: Canonization and Legitimization}

Based in the context of the "Saikaku boom" of the late 1880s and early 1890s, the work of Ozaki Kōyō and Watanabe Otowa in constructing and prefacing Saikaku zenshū becomes more clear. As the leader of Ken'yūsha, Kōyō not only had a great deal at stake in attempting to popularize his favorite author, but also stood to benefit from the associated legitimization of his own experiments in Saikaku's style - and stood to lose quite a bit if this legitimization failed. We can read Saikaku zensh $\bar{u}$ - both the names of its editors and their literary critical prefaces - in light of the reprinting of Saikaku's works in Ken'yūsha journals, Rohan's lengthy (and laudatory) critique, and Roan's ranking of Saikaku among the "top three novelists" in Japanese literature. While Roan and Rohan were not Ken'yūsha affiliates, they published alongside them - for example, Roan's article in the Ken'yūsha magazine Shōbungaku, and Rohan's editing, with Kōyō (published posthumously in 1903-05), of the collection Saikaku bunsui (The Essential Saikaku). This allows us to better appreciate the mutual legitimization that takes place when two editors, and multiple other writers, make the case for an author whose style they have publicly embraced and even imitated - and more personally, collected and fervently read themselves. Moreover, it gives us an understanding of the context of the cultural work they performed as ardent, personally-invested advocates of Saikaku, which I will address at greater length below and argue is an essential aspect of his invention and popularization. 
Of course, the work of a single collection alone could not canonize Saikaku, or even serve to establish him as a legitimate modern author. We can view Saikaku zenshū as a manifestation of a larger process: a contemporary conversation about Saikaku that kept him in the minds of those discussing the direction and concrete techniques of Japanese literature, and that associated him inseparably with Ken'yūsha members. This conversation is key to our understanding of Saikaku's continued popularity and importance in narratives of Japanese literary history. As Wendell Harris posits, canon formation is not "a work's acceptance into a severely limited set of authoritative texts," but rather a work's "introduction into an ongoing critical colloquy." ${ }^{58}$ Literary canons themselves "propose entries into a culture's critical colloquy," and involve not simply texts but "texts as read." ${ }^{59}$ Jane Tompkins, similarly, argues that "the canon not only can but will change with the circumstances within which critics argue." ${ }^{60}$ In this view, the criteria for canonization depend on the historical moment in which a work is introduced, and on the moments that come thereafter. A work and its author are not guaranteed perpetual popularity, but rather must have some qualities that continue to make them culturally relevant in new ways as historical circumstances change. It is crucial, moreover, to keep in mind that those qualities will resonate with certain human actors who then do the cultural work of advocating for that author or work, introducing the conversation and keeping it going.

At the time Saikaku zenshū was published, Saikaku's work had failed to meet Tompkins's test: he had been mostly ignored for about two centuries. Yet in the 1880s and 1890s he began to get traction and was discussed and reprinted in different venues; aside from Saikaku zenshū, selections of his works were collected - also by Ozaki Kōyō and Kōda Rohan - in Saikaku bunsui in (1903-1905), a fascinating volume bound in traditional Japanese style, rather than in

\footnotetext{
${ }^{58}$ Wendell Harris, “Canonicity," PMLA 106, no. 1 (January 1991), 111.

${ }^{59}$ Harris $111,117$.

60 Tompkins, 4.

Copyright (C SHARP. This article first appeared in BOOK HISTORY, Volume 20, 2017, pages 274-306.
} 
the Western binding that was used for the 1894 collection. As early as January 1890, Aeba Kōson began an article on two early modern playwrights by reminding readers of Saikaku's prominence as the foremost Genroku prose author, and introduced the first of the playwrights, the now canonized Chikamatsu Monzaemon, as occupying that same lofty place in literary history. Even a mention of Saikaku here is enough to contextualize Kōson's discussion of two writers from very different genres for readers of a general-interest magazine. He found his way into the academic world in time, too: in their 1893 volumes attempting to narrate a history of Japanese literature, Nihon bungakushi, Mikami Sanji and Takatsu Kuwasaburō describe Saikaku as "observing the emotions and customs (ninjō füzoku) of the people of his time, and recording the speech and clothing and so on," noting that other Edo authors such as Kyokutei Bakin did so as well. ${ }^{61}$ Saikaku here is not unique, but is part of the conversation of Edo literature already -yet, different from Ken'yūsha's advocacy in that it is more an impartial description, not an argument for his relevance as an author for contemporary questions about literary values.

Meanwhile, in his 1899 History of Japanese Literature, W. G. Aston also singles out Saikaku as an Edo author (if derisively), using the phrase "contemporary life and manners," and "manners and customs," to describe what Saikaku's subject matter. ${ }^{62}$ Interestingly, he also claims that "it is only recently that a new edition [of Saikaku's works] has been permitted to appear, the reason for this tolerance being perhaps the circumstance that the fugitive humor of fast life in the seventeenth century has become in a great measure unintelligible to modern readers." ${ }^{63}$ While it is true that Saikaku's works were suppressed, and even Saikaku zenshü itself was censored with small circles in place of certain words in the stories (it was banned until the publisher made this

\footnotetext{
${ }^{61}$ Mikami Sanji and Takatsu Kuwasaburō, Nihon bungakushi vol. 2 (Tokyo: Kinkōdō, 1894): vol 2., 232. While the publication date is 1894, the colophon notes it was printed in 1893, and thus was written before the publication of Saikaku zenshü. We can only attribute the inclusion of Saikaku here to the conversation about him in the media at the time, and his other reprinted works, not to the Hakubunkan collection itself.

${ }^{62}$ W. G. Aston, A History of Japanese Literature (New York: D. Appleton and Company, 1899): 268.

${ }^{63}$ Ibid, 269.

Copyright (C) SHARP. This article first appeared in BOOK HISTORY, Volume 20, 2017, pages 274-306.
} 
concession), we can hardly say that Saikaku's works were "unintelligible to modern readers" given his popularity among the literati of the late 1880 s and 1890s, and going forward. Even with Aston's disdain for Saikaku's poetry and prose, calling him "a man of no learning" and claiming that he "has written one decent book" only, we can see that there was a certain discourse surrounding both literature and Saikaku at the time Saikaku zensh $\bar{u}$ was published, and it used the same kind of wording that, for example, Shōsetsu shinzui did in 1885. Saikaku, it seems, fit into a larger narrative of what literature's goals ought to be and the public discussion of how to achieve those goals, no matter the attitude of individuals toward the worth of his works. And for Ken'yūsha members such as Kōyō, Saikaku's very style was one of the options for pursuing those goals.

Just as important is the inclusion of Saikaku in continued conversations about literary analysis and personal investment. Not only was Saikaku identified as an Edo writer with his own specific time period, but he was also discussed in trans-historical context with work that both precedes and succeeds his own. In 1907 he was included in a 22-page comparative analysis, "Genji monogatari to 'Kōshoku ichidai okoto' to Beru, am $\vec{\imath}$ in the literary and academic Mita bungaku magazine. ${ }^{64}$ Much later, in 1932, we find advertisements for Saikaku's "complete annotated kōshokubon" (often translated as "works about amorous love") surrounding a critical piece on the future of Japanese literature, and alongside that piece ran a column of writers' and critics' opinions about Saikaku himself. ${ }^{65}$ The advertisements here, too, place him in the same category as other literature considered classics even before this period: annotated versions of Taketori monogatari, Murasaki Shikibu nikki (the diary of the author of The Tale of Genji), Makura no sōshi (The Pillow Book), and Saga nikki (The Saga Diary). The phenomenon of

\footnotetext{
${ }^{64}$ Sōma Gyofū, "Genji monogatari to Kōshoku ichidai otoko to Beru, amī,” Mita Bungaku 1(3), 129-152. The Western work in question appears to be Pere Amie.

${ }^{65}$ See the advertisements and articles in Sakuhin 5 (May 1932), 56-57.

Copyright (C SHARP. This article first appeared in BOOK HISTORY, Volume 20, 2017, pages 274-306.
} 
Saikaku in the 1880s was far from short-lived, and we can see that at least until the 1930s, he was seen as a writer with whom to be engaged, not a distant object for study only in his historical moment. Saikaku here was perhaps just as contemporary as lauded tales and current French literature, and he was open for critical discussion just as was the future of literature. He was still living literature even in 1932, much as he had been to Ken'yūsha and their contemporaries.

Jane Tompkins argues that "novels and short stories ... offer powerful examples of the way a culture thinks about itself, articulating and proposing solutions for the problems that shape a particular historical moment." ${ }^{66}$ This proposition applies equally well to the work of compilers and editors, as well as those who advertise and promote books and writers, and it is a useful way to think about the attempts at legitimization that we find in and around Saikaku zensh $\overline{\text {. Saikaku }}$ himself was long dead by the 1890s, and his fiction had been written for a different audience at a very different historical moment, as Aston alludes to in his claim that it would be almost completely foreign to readers of the day. There was a major question at this time, though, that permeated most areas of society: What does modern Japan look like? Is Westernization appropriate, and if so, how would Japan appropriate and introduce specific cultural, scientific, and technological elements? In the area of literature, the question was similarly fundamental. As late as the 1890s, the question of what qualified as literature - the definition of bungaku itself (usually translated as "literature") - was an open one, and debates continued over the form, style, and content of both fiction and poetry. ${ }^{67}$ Moreover, there was a disconnect between advocating for Western-style novels and new uses of language in fiction, and what Japanese were actually reading: earlier nineteenth-century fiction written in a somewhat different style was still popular

\footnotetext{
${ }^{66}$ Tompkins, xi.

${ }^{67}$ The experimentation with style in novels was joined by advocates for free-form poetry and translations of Western poetry into styles resembling traditional Japanese poetry. For example, see Shintaishishō, Kitamura Tōkoku's Soshū no shi, and Shinseisha's famous poetic translation Omokage.

Copyright (C SHARP. This article first appeared in BOOK HISTORY, Volume 20, 2017, pages 274-306.
} 
and actively in circulation. ${ }^{68}$ Saikaku zensh $\bar{u}$ was published at an extraordinarily turbulent historical moment, not just for literature but for Japan as a whole, and it came at just the time when it had the potential to answer a fundamental question: what is the future of Japanese literature?

In analyzing the writing of histories of Japanese literature beginning in 1890s, Michael Brownstein argues that "the revival of interest in pre-modern literature in the 1890s was part of a larger public reaction to the excesses of Japan's Westernizing policies." ${ }^{69}$ It was indeed at this time that the first histories of pre-modern literature were being written by scholars such as Mikami Sanji and through these, as well as departments in universities, that a pre-modern canon was being developed by academics. ${ }^{70}$ In addition, publishers began to print typeset versions of pre-modern works such as monogatari ("tales") and publish these on a mass scale, such as the series Nihon bungaku zensho (The Complete Works of Japanese Literature). In fact, the successor to this series was none other than The Imperial Library, in which Saikaku zenshū was published. Yet The Imperial Library reprinted popular works of early modern fiction and, in this way, can hardly be called part of a revival of pre-modern or even early modern literature. These were mostly living works that were still being read, even if they might have been printed using movable type for the first time in that series. With this in mind, it is interesting that Saikaku's works were published in the context of The Imperial Library and its "living literature." Was it simply the convenience of having a series published by a Ken'yūsha friend that might have room for another couple of installments, or were Ozaki Kōyō and Watanabe Otowa trying to market

\footnotetext{
${ }^{68}$ See P. F. Kornicki, "The Survival of Tokugawa Fiction in Meiji Japan," Harvard Journal of Asiatic Studies 41, no. 2 (December 1981): 461-482.

${ }^{69}$ Michael C. Brownstein, "From Kokugaku to Kokubungaku: Canon-Formation in the Meiji Period," Harvard Journal of Asiatic Studies 47, no. 2 (December 1987), 436.

${ }^{70}$ See Brownstein for an extended discussion of this movement in the $1890 \mathrm{~s}$ and $1900 \mathrm{~s}$.

Copyright (C SHARP. This article first appeared in BOOK HISTORY, Volume 20, 2017, pages 274-306.
} 
Saikaku as someone with whom to engage as current literature rather than a dead classic through inclusion in this type of venue $?^{71}$

It is not uncommon for Saikaku's adoption and promotion to be seen as an act of resistance against Westernization, and of the adoption of Western literary styles and forms in particular. To be sure, the very idea that the Western novel (as interpreted and translated by writers and critics) was the form that serious writers should pursue in order to produce valuable literature was nearly ubiquitous. It is Ken'yūsha in particular that is now known as resisting the turn to the West, regardless of whether the description of their work as resistance is accurate, partly because of their interest in Saikaku. As Yone Noguchi, the early twentieth-century critic put it for an American audience in 1904,

... the public were looking for some kind of reaction [against English literature]. They began to take up their kimonos again, leaving the badly fitting trousers behind. Saikaku Ibara (sic) - the foremost of the Genroku writers - was suddenly resurrected from the darkness of oblivion. ${ }^{72}$

Although we can say that Saikaku was in some sense "resurrected from the darkness of oblivion" where had laid for centuries as far as widespread popular readership is concerned, Noguchi's description of resistance does not fit with the reality of Saikaku and his adoption. Kōyō and his colleagues were, in a way, hardly bucking the larger literary trends of engaging with depicting "emotions, customs, and manners," the very same goals that Atsuko Ueda identifies as "Shōsetsu shinzui clichés" -- part of a much larger discourse about the mission of literature in general. As we have seen, even the disparaging entry in Aston's Japanese Literature describes Saikaku as representing the "customs and manners" of his time. By supporting and advocating for Saikaku and his skill in description of people's emotions and lives in the Genroku

\footnotetext{
${ }^{71}$ Watanabe Otowa soon became Ōhashi Otowa, marrying into the Ōhashi family that owned Hakubunkan, Saikaku zenshü's publisher.

${ }^{72}$ Noguchi, 262.

Copyright (C SHARP. This article first appeared in BOOK HISTORY, Volume 20, 2017, pages 274-306.
} 
period, Ken'yūsha and their allies were participating in an active debate about not necessarily what the goal of literature ought to be, but rather the methods of reaching agreed-upon goals. The idea of a "modern literature" crafted after Saikaku and other Genroku writers and artists was looked at in the very same framework as all other modern literature. Here, Ken'yūsha's Ihara Saikaku was a living author to be engaged in the framework of the present.

The focus on where Saikaku falls in contemporary literary movements is telling of how he was being thought of and engaged with by Rohan and other late nineteenth-century readers. As Jonathan Zwicker argues, the structure, style, and content of Saikaku's writing was strikingly different from other genres that were popular in the nineteenth century - including, interestingly, the very genres to which he Kōyō and Otowa liken him in Saikaku zenshū's prefaces, such as Edo ninjōbon, which were focused on plot and action. Saikaku would have been just as new and "foreign" to Meiji readers as were some Western writers whose work similarly deviated from the plot-based novel, such as Tolstoy. ${ }^{73} \mathrm{He}$ cannot be thought of as simply a turn to the past; rather, as Zwicker puts it, both Saikaku and Tolstoy "seemed to offer a new departure" from earlier nineteenth-century literature, and represented "a new type of reading" — what he refers to as "art for art's sake," rather than novels read for plot. ${ }^{74}$ The picture of Saikaku is much more complex than writing him off as the fixation of a group of writers "[taking] up their kimonos again," and we must see him as the truly new invention that he was in the 1890 s.

\section{Saikaku Zenshū: A Social Map of Literary Space}

Saikaku zensh $\bar{u}$ asks, in its very construction, for us to examine the social space that produced it, from its compilation to its journey through the presses and into the hands of readers.

\footnotetext{
${ }^{73}$ Jonathan Zwicker, Practices of the Sentimental Imagination: Melodrama, the Novel, and the Social Imaginary in Nineteenth-Century Japan (Cambridge, MA: Harvard East Asia Center, 2006), 165.

${ }^{74}$ Ibid., 171, 167-168.

Copyright (C SHARP. This article first appeared in BOOK HISTORY, Volume 20, 2017, pages 274-306.
} 
We have already seen that this collection was published in a certain context of advocacy for its author, and that it reveals the network of people that made that advocacy possible in the first place through its specification of the social provenance of the texts that his advocates could get ahold of. We must understand Saikaku's popularization in the late nineteenth century as produced actively, using new media and communication technologies of the time, by Saikaku partisans in a milieu of attempting to answer questions about the direction of Japanese literature. It was a process driven by specific people and groups that are laid bare in Saikaku zenshū through its editorial staff and the social provenance marked within its covers; those individuals actively used the technologies newly available to them to disseminate their points of view, including the making of Saikaku zenshü itself, and the volumes hardly materialized on their own. This collection is key in that, unlike most, it reveals to us both the network and, by implication, the processes behind its construction, distribution, and potential reception.

The late-nineteenth-century fascination with and promotion of a figure who lived centuries earlier, while using quite different media technologies, have some parallels in the cult status of some twentieth- and twenty-first-century films, television series, comics, and creators. These moments are similar in terms of the culture of communications technology: they are both periods of great change and rapid modernization, with the industrial printing press and emerging postal and rail systems characterizing the Meiji period, while the turn of the latter century has experienced the rise of the Internet and accompanying digital channels for social connections. These modes of communication sparked revolutions at both times, in terms of being able to foster a discourse and distribute works outside of established publishing industries, and they contradict any claim that these ages were (and are) dominated by mass-produced, top-down cultural products. Moreover, they share similarities in the deep personal investment of fans in 
media that may have either never been popularly acclaimed or have fallen out of favor; this investment and resulting conversation among first a few, then many more, are part of what ensure that certain authors or works can become a part of the canon later. Although that conversation does not guarantee canonization, it is a necessary component of the process, and in the case of Saikaku, certainly drove his later place in the historical pantheon of Japanese authors.

There is admittedly a gap between scholarship on contemporary fan culture and the case we are trying to comprehend in the late nineteenth century. This is not, however, due to irreconcilable differences in consumption and reception brought about by the advent of mass media in the twentieth century and the Internet at the turn of the current one. Scholarship in fan studies tends to be overly specific to twenty-first-century conditions and arguments are often technologically deterministic; moreover, scholarship in this field tends to treats mass media as though it has always existed (and thus that participatory culture is new and unique to the Internet age). Many scholars argue that modernization brought about corporations, especially in the twentieth century, that have always been able to enforce a top-down interpretation and usage of their intellectual property. They set up a false dichotomy between an imagined passive consumer and "newly"-emerged participatory fan. Yet as Mark Duffett points out in his Understanding Fandom, the specific historical conditions from which fandoms originate "stem from shifts in media and their tendency to reconfigure everyday experience." ${ }^{75}$ I propose that if we make clear the conditions which brought about the specific historical moment we are examining, we can broaden the field to include moments such as the Saikaku boom of the late nineteenth century, which, while not identical to the phenomenon of contemporary fandom, shares similarities in the active cultural work performed by his advocates, both in popularization and imitation. By doing

\footnotetext{
${ }^{75}$ Mark Duffett, Understanding Fandom: An Introduction to the Study of Media Fan Culture. (New York: Bloomsbury, 2013), 5.

Copyright (C SHARP. This article first appeared in BOOK HISTORY, Volume 20, 2017, pages 274-306.
} 
so, we can refine our understanding of Saikaku's late-nineteenth-century invention, and the ways in which authors and critics are motivated to participate in the debates that characterized the development of fiction at that moment in history.

Ultimately, Saikaku's emergence in the 1880s and 1890s would not have been possible without not only his uncovering by the Ken'yūsha coterie, but also without industrial printing technology introduced to Japan after the Meiji Restoration (1868); this allowed for the production of Saikaku zenshū on a scale that simply would not have been possible with the woodblock printing technology prevalent just several decades before. ${ }^{76}$ Moreover, the collection was available through another new resource in terms of communications technology: the Japanese postal service. This network, which used the growing rail system throughout the nation, facilitated the subscription services that became so popular both at this time and later (for example, with the first large-scale zensh $\bar{u}$, The Complete Works of Contemporary Japanese Literature in the 1930s in one-yen book format). ${ }^{77}$ This system additionally made possible Ken'yūsha's earlier exchanges among its members and with those outside the group in the form of printed journals that could be obtained through networks that allowed for unintended audience members to discover, read, and respond to the material. While, again, this would not have been impossible earlier in the nineteeth century, it could take place on an unprecedented geographic scale, and those reached through the publications could then interact with them in the form of letters to the editors and submissions of material. Like the Internet fan cultures we see today, interacting on a scale unprecedented before the advent of globally-connected IRC channels,

\footnotetext{
${ }^{76}$ This is not to say that woodblock printing did not produce many copies; however, blocks would have to be recarved after a certain number of printings, thus limiting the runs and creating a financial burden on printers if they were to print many thousands of copies of a volume.

${ }^{77}$ For more on this series, the Gendai Nihon bungaku zenshū 現代日本文学全集, see Edward Mack, Manufacturing Modern Japanese Literature: Publishing, Prizes, and the Ascription of Literary Value, Durham: Duke University Press, 2010.

Copyright (C SHARP. This article first appeared in BOOK HISTORY, Volume 20, 2017, pages 274-306.
} 
interest-based forums, and social media, this something that was not imaginable before the advent of the newly-legalized magazine, as well as newspapers, in the Meiji period.

Key in linking Ken'yūsha to the popularization of Saikaku, these coterie journals gave its members such as Ozaki Kōyō an avenue to distribute their work that was based on their interpretations of Saikaku's style and content; these were published using industrial equipment imported from the West that were often owned by their personal acquaintances and friends. ${ }^{78}$ Kōyō's writing in these publications then lead to wider circulation in book format such as with his first major novel, Irozange, published in 1889 in the Shincho hyakushu (A Hundred Varieties of New Writing) series of novels by young authors. ${ }^{79}$ Ken'yūsha and others' coterie magazines were perhaps not so dissimilar from current self-publishing mechanisms via Internet technologies as well as corporations. They perform a similar function: allowing fans' responses to their favorite works to reach a broad and sometimes unexpected audience, while also feeding back into the popularity of the original works by spreading knowledge of their existence and fans' investment in them. At the same time, we find knitted together a core support community within those sites, facilitating the further "publishing" of reactions to various creations and creating a conversation among interested parties - often among the very people who published in the same spaces. In other words, this was not just a Saikaku conversation, but a Saikaku community. In this way, Ken'yūsha's publishing activities, while taking place in a non-digital format and on a much smaller scale, resemble those actions that take place within the twentyfirst-century digital environment.

\footnotetext{
${ }^{78}$ Especially important for the case of Saikaku zensh $\bar{u}$ is Kōyō's connection with fellow editor Watanabe, later Ōhashi, Otowa, who became the head of major publisher Hakubunkan after his marriage into the family. Hakubunkan was the publisher of Saikaku zenshū.

${ }^{79}$ This is the same series that included Kōda Rohan's famed 1889 work, Fūryü butsu. Once again, we find the same small circle of writers -- even if they didn't belong officially to the same coteries -- publishing together.

Copyright (C SHARP. This article first appeared in BOOK HISTORY, Volume 20, 2017, pages 274-306.
} 
While Ken'yūsha's colleagues may not have had search engines to draw them to Saikaku "fan fiction" such as Kangetsu's late-1880s publications in Bunko written with pen names that directly referenced him, ${ }^{80}$ they had a nineteenth-century equivalent; word-of-mouth referrals and book reviews in prominent publications, such as Kokumin no tomo, could alert them to new works published outside of journals and magazines. Meanwhile, those that were published in journals could reach readers through their regular reading and also friends and acquaintances who might have received these publications through their social networks, such as the handcirculated and annotated early Garakuta bunko. These new networks were facilitated both by technology and the education system, which brought together core Ken'yūsha members in geographic proximity to each other. This allowed for a cementing of social bonds via shared literary interests, and made possible the sharing of hand-written collections of their experimental works with each other. In fact, the creation of Garakuta bunko before and even during its typeset printing phase resembles contemporary, late twentieth- and early twenty-first-century zines, circulated to a limited network of people.

This tightly knit social network, however, had wider implications. Because of the fame of some members, their work became known beyond the borders of their group starting in about 1889 and they were able to insert Saikaku into a larger conversation in publications with greater reach, such as with Rohan's article in Kokumin no tomo. In 1894 came Saikaku zenshū itself, with the importance and relevance of the author's work promoted by Ken'yūsha editors in its prefaces and circulated by its publisher in a series of still-popular fiction. The editors' personal investment, and that of their colleagues, created something that did not previously exist: "Ihara Saikaku" the author, the short story writer, the anthropologist focused on "manners and customs," and a writer to be engaged and reinterpreted in a modern context. And their publishing

\footnotetext{
${ }^{80}$ Here, he used the name "Aikakuken". Literally, it can be interpreted as "I love Saikaku."

Copyright (C SHARP. This article first appeared in BOOK HISTORY, Volume 20, 2017, pages 274-306.
} 
activity ensured that his name would circulate, even to the present day (if in a somewhat different context). It is not an exaggeration to say that this continued conversation about Saikaku owes much to collectors' digging in bookstores, and Ken'yūsha's republishing, promoting, stylized fiction, and constant discourse about him: their fan-esque culture made it possible for him to enter our canon of Japanese literature today.

Ultimately, this raises questions about how creative production and media circulation interact with culture and fandom. As the case of Saikaku demonstrates, fan culture is not necessarily a novel phenomenon unique to the contemporary period. The Saikaku boom and advocacy took place just as mass media was beginning in Japan, if we mark the introduction of industrial printing as well as newspapers and magazines in the 1870 s as its inception. ${ }^{81}$ Saikaku's fan base used the very same technology as the mass media did, using new communication methods as a way to circulate their views and creations. We can hardly say that before the Internet, there was no participatory culture. Ken'yūsha engaged not only with Saikaku, a longdead inspiration, but also adapted contemporary Western novels' plots and characters to form their own stories. ${ }^{82}$ They created work fed with input from a variety of sources and their peers reacted to their work by directly participating in the discourse of the publications in which it appeared, from letters to the editor to writing their own articles in response. It was a space of critical engagement and play, and for active engagement with ideas and passions that completely preoccupied the literary world of Meiji Japan, about what it meant to be Japanese, what Japanese literature could mean, and what modernity could look like.

\footnotetext{
${ }^{81}$ One major difference is that newspapers were banned before the middle of the nineteenth century, thus limiting circulation of information on a large scale, although that did not stop the printers of broadsides and other media from engaging slyly with political events, disasters, and scandals. It is partly for this reason that I would mark the introduction of newspapers via industrial printing as the beginning of a truly mass media in Japan.

${ }^{82}$ Ozaki Kōyō's The Golden Demon (Konjiki yasha) is only the most well known of these works, which is said to be modeled on Bertha M. Clay's Weaker Than a Woman (first serialized in 1878). See Sakai Miki, Ozaki Kōyō to hon'an: sono hōhō kara yomitoku 'kindai' no gugen to genkai (Tokyo: Hana shoin, 2010).

Copyright (C SHARP. This article first appeared in BOOK HISTORY, Volume 20, 2017, pages 274-306.
} 
We also need to recognize that for the literary world of Meiji, as the names on Saikaku zenshū demonstrate, Saikaku was not just an idea: he was Ken'yūsha's idea and their author to promote. Saikaku was inextricably associated with this group and its literary and social tendencies, not a literary concept encountered in a vacuum. He couldn't be talked about at the time without also implicitly referencing Kōyō, Rohan, Kangetsu, or their colleagues, and he was embedded in their publication space and their literary endeavors. We now read Saikaku standing on his own, placed in the context of a pantheon of Edo writers or Japanese literary greats. He is no longer associated with a specific social group, one sometimes derided as retrograde in a modern world, yet comprised of best-selling authors whose names were everywhere in the media of the time. We no longer think of Saikaku as a Meiji phenomenon. Yet this is the context in which those who witnessed his invention and canonization inevitably read him, and he functioned as a possession of his fans. In this way, his popularization and legitimization was a reflexive risk and opportunity for Ken'yūsha: if they failed in their advocacy, by implication, their own work would be delegitimized as well. But if they succeeded in making Saikaku newly relevant to their colleagues, they in turn made their own work and criticism relevant to modern Japanese literature as well.

Our familiarity with Saikaku as a canonized author of short fiction attests to qualified success of Ken'yūsha and allies' advocacy for his legitimate relevance to a late nineteenthcentury audience. They established Saikaku in the literary world and Japanese literary history, with an endpoint firmly in the present moment, and they left their names in the very pages of Saikaku zensh $\bar{u}$ - a work that made him even more accessible to new audiences both literary and popular. Through their intellectual and publishing endeavors, they leave us with evidence of the process by which Saikaku was brought into the modern period and made available, and a topic of 
conversation, for others to engage with and sustain over time. Yet at the same time, Ken'yūsha's members and their work have largely been forgotten; their Saikaku-inspired style did not win out over other types of new writing by authors such as Futabatei Shimei and Mori Ōgai. Their passionate advocacy of the author, and social association with him and his promotion, has likewise not survived. Saikaku as an integral part of Ken'yūsha's style ended with Kōyō's death in 1903, if not earlier; his disciples who are well known today, such as Izumi Kyōka, are not associated with the Edo writer. Yet the case study of Saikaku zenshū and the literary events that led up to and surrounded its publication give us insight into the human process of making a work and author available for canonization. It demonstrates the very human process of "archiving" an oeuvre - made abundantly clear by the inclusion of social provenance - that makes literary legitimization and popularization possible in the first place. It demonstrates how an author is invented, and how that invention may stem from the passions of a few dedicated individuals with personal connections to those who could help them successfully advocate for the object of their literary admiration. Saikaku zenshü's construction, especially its social provenance, reveals to us how an author is invented and promoted using the technologies and resources at hand, and the human element that drove that invention and promotion at a pivotal moment in the history of Japanese literature and publishing. 


\section{Bibliography}

Aeba Kōson. "Chikamatsu Monzaemon to Takeda Izumo.” Kokumin no tomo 71 (January 1890): 28-31.

Aston, W. G. A History of Japanese Literature. New York: D. Appleton and Company, 1899.

Awashima Kangetsu. 'Ihara Saikaku zatsuwa," in Bon'un'an zatsuwa, 87-92. Tokyo: Heibonsha, 1999.

Awashima Kangetsu. "Meiji jūnen zengo," in Bon'un'an zatsuwa, 29-36. Tokyo: Heibonsha, 1999: 32.

Brownstein, Michael C. "From Kokugaku to Kokubungaku: Canon-Formation in the Meiji Period." Harvard Journal of Asiatic Studies 47, no. 2 (December 1987): 435-460.

Cook, Terry. "What is Past is Prologue: A History of Archival Ideas Since 1898, and the Future Paradigm Shift.” Archivaria 43 (Spring 1997): 1-43.

Dowdle, Brian C. "Why Saikaku Was Memorable but Bakin Was Unforgettable." Journal of Japanese Studies 42, no. 1 (January 2016): 91-121.

Duff, Wendy M. and Verne Harris. "Stories and Names: Archival Description as Narrating Records and Constructing Meanings." Archival Science 2 (2002): 263285.

Duffett, Mark. Understanding Fandom: An Introduction to the Study of Media Fan Culture. New York: Bloomsbury, 2013, 5.

Fuchian Shujin [Uchida Roan]. "Nihon shōsetsu no san taika." Shōbungaku 1 (October 1889): 11.

“Garakuta Bunko: Dai-jūni-gō Ken'yūsha hakkō.” Kokumin no tomo 25 (July 1888): 31-32.

Harris, Wendell. “Canonicity.” PMLA 106, no. 1 (January 1991): 110-121.

Ihara Saikaku. "Kōshoku ichidai onna.” Bunko 24 (July 1889): 47-49.

Ihara Saikaku. "Kōshoku nidai otoko.” Shigarami zōshi 1 (October 1889): 47-48.

Ihara Saikaku. Kōtei Saikaku zenshū. Edited by Ozaki Kōyō and Watanabe Otowa. Vol. 23-24 of Teikoku bunko. Tokyo: Hakubunkan, 1894. 
Ihara Saikaku. Saikaku bunsui. Edited by Ozaki Tokutarō [Ozaki Kōyō] and Kōda Nariyuki [Kōda Rohan]. 3 vols. Tokyo: Shun'yōdō, 1903-1905.

Ihara Saikaku. "Yakusoku wa yuki no asameshi.” Shōnen'en 55 (February 1891): 16-17.

Inuguchi. "Tsuretsure.” Iratsume 81 (March 1891): 136.

Kashi Rohan [Kōda Rohan] and Aikakuken Saiseki [Awashima Kangetsu]. "Ihara Saikaku o tomurau bun.” Shōbungaku 2 (November 1889): 13-14.

Katsumoto Sei'ichirō. "Rohan to Kōyō.” In Rohan zenshū furoku, 22-25. Tokyo: Iwanami shoten, 1980.

Kawakami Akira. Bizan zenshū. Tokyo: Hakubunkan and Shun'yōdō, 1909.

Keene, Donald. World Within Walls. New York: Holt, Rinehart and Winston, 1976.

Kōda Rohan. "Ihara Saikaku.” Kokumin no tomo 83 (May 1890): 27-31.

Kornicki, P. F. "The Survival of Tokugawa Fiction in the Meiji Period.” Harvard Journal of Asiatic Studies 41, no. 2 (December 1981): 461-482.

Mack, Edward. Manufacturing Modern Japanese Literature: Publishing, Prizes, and the Ascription of Literary Value. Durham: Duke University Press, 2010

Mikami Sanji and Takatsu Kuwasaburō. Nihon bungakushi. 2 volumes. Tokyo: Kinkōdō, 1894.

Noguchi, Yone. "The Evolution of Modern Japanese Literature." The Critic 3, no. 44 (March 1904): 261-263.

Sakai Miki. Ozaki Kōyō to hon'an: sono hōhō kara yomitoku 'kindai' no gugen to genkai. Tokyo: Hana shoin, 2010.

Sanmai Dōjin [Miyazaki Sanmai]. "Watashi to Saikaku.” Kōchō 5 (1906): 11-16.

Shirane, Haruo, ed. Early Modern Japanese Literature, a Collection, 1600-1900. New York:

Columbia University Press, 2002.

"Shomoku jisshu." Kokumin no tomo 48 supplement (April 1889): 1-18.

"Shomoku jisshu." Kokumin no tomo 49 (April 1889): 30-32.

Sōma Gyofū. "Genji monogatari to Koshoku ichidai otoko to Beru, amii." Mita Bungaku 1 , no. 3, 129-152.

Tompkins, Jane. Sensational Designs: The Cultural Work of American Fiction 1790- 
1860. New York: Oxford University Press, 1985.

Ueda, Atsuko. Concealment of Politics, Politics of Concealment: The Production of "Literature" in Meiji Japan. Stanford: Stanford University Press, 2007.

Zwicker, Jonathan. Practices of the Sentimental Imagination: Melodrama, the Novel, and the Social Imaginary in Nineteenth-Century Japan. Cambridge, MA: Harvard East Asia Center, 2006. 